\title{
EXPLORATION OF AGENT-BASED SIMULATION: THE MULTIPLIER EFFECT OF ZAKAH ON ECONOMIC GROWTH ${ }^{1}$
}

\author{
Diyah Putriani ${ }^{1}$, Gairuzazmi Mat Ghani ${ }^{2}$ and Mira Kartiwi ${ }^{3}$ \\ ${ }^{1}$ Universitas Gadjah Mada, Indonesia, diyah.putriani@ugm.ac.id \\ ${ }^{2}$ International Islamic University Malaysia, Malaysia, gairuzazm@iium.edu.my \\ ${ }^{3}$ International Islamic University Malaysia, Malaysia, mira@iium.edu.my
}

\begin{abstract}
Zakat plays an undeniably significant role in social life. The enforcement of zakah in early Islamic history is evidence that it is a powerful tool for fostering economic growth. The economy under the reign of Caliphate Umar Ibn Abdul Azis even achieved a surplus, with no one having the right to receive zakah. Recent studies have attempted to link the role of zakah and economic growth qualitatively by arguing that zakah can contribute to economic development. However, the extent to which it has a multiplier effect on economic growth has not been examined. Considering this research gap, this study examines such an effect on economic growth, as represented by Gross Domestic Product (GDP). To capture the full impact of zakah on aggregate production, two scenarios are conducted, namely the economy with and without zakah. The simulation results show that zakah can promote aggregate production. On the other hand, the economy experiences lower aggregate production when there is no zakah. An agentbased computational model (ABM) simulation is employed to run the simulation. The application of ABM in this study is intended to introduce the use of computational study as an alternative method of developing research in Islamic economics.
\end{abstract}

Keywords: Zakah, Aggregate production, Bank lending, Agent-based computational model, Islamic economics. JEL Classification: C61; C63; E23; O10; O49.

\author{
Article history: \\ Received : October 8, 2019 \\ Revised : November 25, 2019 \\ Accepted : July 6, 2010 \\ Available online : August 25, 2020 \\ https://doi.org/10.21098/jimf.v6i3.1110
}

\footnotetext{
1 The corresponding author would like to thank LPDP (Lembaga Pengelola Dana Pendidikan), Ministry of Finance, Republic of Indonesia, for the award of a research endowment. In addition, the authors would like to thank the reviewers for their instructive comments and valuable inputs.
} 


\section{INTRODUCTION}

\subsection{Background}

The goals and values of Islamic economic teachings include universal brotherhood and justice, economic well-being under the umbrella of Islamic moral norms, equitable distribution of income, and the ensuring of social wellbeing across all levels of society (Chapra, 1979). To attain these goals, Islam strongly condemns those who hoard wealth. Many verses in the Quran and hadith command that individual wealth should not only benefit its respective owners, but also be distributed fairly throughout society (Ismail, 2010). The Islamic economics literature suggests the building of instruments of wealth redistribution, such as zakah, voluntary sectors, which include infaq, sadaqah and waqf, and an equitable inheritance system. These Islamic redistributive instruments are proposed as effective means of attaining wealth equality.

Zakat is the only instrument which is enforced for those who are categorised as muzaki and paid based on the nissab measure; on the other hand, other instruments are principally voluntary. Furthermore, zakah is always associated with the five times-a-day prayers in the Quran and revealed numerous times in the Hadith. The Prophet (PBUH) said "It should be taken from the rich class of society and it should be distributed amongst the poor class of the society "2.

The significant role of zakat in individual and social life is undeniable. Recent empirical studies support the notion that zakah promotes not only beneficiaries' consumption (Ayuniyyah et al., 2017 ; Nurlita \& Ekawaty, 2018; Suprayitno et al., 2013), but also reduces poverty (Ahmed, 2004; Ayuniyyah et al., 2017; Bello, 2010; Hassanain \& Ali, 2016; Hoque, Khan, \& Mohammad, 2015; Jaelani, 2016; Kasri \& Kassim, 2009, amongst many others). Therefore, zakah is argued to be a potential instrument of social security (Ziauddin, 1990).

The enforcement of zakah in early Islamic history is evidence that it is a powerful tool for fostering economic growth. The economy under the reign of Caliphate Umar Ibn Abdul Azis even achieved a surplus, with no-one having the right to receive zakah (Akbar \& Kayadibi, 2013). Recent studies have attempted to link the role of zakah and economic growth qualitatively by arguing that zakah can contribute to economic development (Sarea, 2012; Azam et al., 2014; Ridwan et al., 2019, among many others). In contrast, Khasandy and Badrudin (2019) found that zakah does not significantly affect economic growth.

The literature, however, has not examined the extent to which zakah has a multiplier effect on economic growth. Considering this research gap, this study examines this effect on economic growth, as represented by Gross Domestic Product (GDP). The study differs from previous literature (Sarea, 2012; Azam et al., 2014; Ridwan et al., 2019; Khasandy \& Badrudin, 2019) in three ways. First, it is potentially the first work to capture and examine the full impact of zakat on economic growth. Second, while previous studies have employed traditional qualitative approaches and employed empirical cases, this study uses an exploratory approach and conducts a simulation as a research method, i.e. the agent-based computational model (ABM). This model was used in order to allow the use of computational study as an alternative method of developing research in

2 Sahih-Muslim 
Islamic economics. Third, this study captures the multiplier effect of zakah at the macro level.

The paper is expected to contribute to the development of Islamic economics research in three ways. First, it examines the multiplier effect of zakah on economic growth. Second, it compares the difference in economic growth before and after zakah enforcement, and third, it highlights the link between economic growth and aggregate consumption.

The study is divided into six parts. The first part introduces the research and discusses the research gap and contribution. The second part reviews the relevant literature, while the third explains the selected research method. The fourth section examines the results and analysis, while the conclusion and policy recommendations are elaborated in the fifth section. Finally, suggestions for future research are made in the sixth section.

\section{LITERATURE REVIEW}

\subsection{Background Theory}

\subsubsection{Complex System}

Under the agent-based computational model (ABM) framework, the structure of the economy is based on a complex system, an example of one which sees the world as a living creature which observes how the interaction between all the agents (or elements) in the system may form a complete pattern, and how this pattern subsequently results in the interacting agents adjusting or changing (Arthur, 2013). Oh (2015) further explains that the interaction between agents has consequences; that is, the individual decisions of each agent are affected by their neighbours (other individuals).

The economic system is an example of a complex system (Al-suwailem, 2011). It is created from a continuously developing set of institutions, arrangements and technological innovations. In this regard, economic agents usually change their acts and plans. For example, firms change their prices depending on previous demand. Therefore, the output decision of an individual is the result of an interaction.

To build a complex system structure, agent behaviour, $x_{i, t^{\prime}}$ is built by independent and relative variables. The independent variable, $z_{i, t-1}$, is defined as being outside the system and exogenous to all agents. Meanwhile, the relative variable, $x_{-i, t-1}$, examines the behaviour of the other agents within the system. In other words, an agent's decision will not only be influenced by the independent variable but also by the relative variables, as a consequence of an agent's interaction with other agents. The complex system can be written as follows (Al-Suwailem, 2008):

$$
x_{i, t}=f\left(z_{i, t-1}, x_{-i, t-1}\right)
$$

The behaviour of the world system cannot be subtracted from the behaviour of its elements and cannot be made uniform for all the elements within it. The interactions between agents arise from micro (local) interactions. Meanwhile, the term 'emergence' refers to the ability of the system to perform a function to solve a problem which cannot be solved by individual agents. Therefore, the 
behaviour of all the agents cannot be seen as linear or as a permanent structure, since the macrostructure is formed by a large number of individual interactions (Al-suwailem, 2007, 2011).

\subsubsection{Zakah and Economic Growth}

Zakat plays a fundamental role in social life. The enforcement of zakah in early Islamic history proves that it was a powerful tool for fostering economic growth, as previously stated. According to Kahf (1999), potential zakah is around 1.8 percent to 4.34 percent of total GDP in each Muslim country, equal to US\$ 600 billion each year. As a majority Muslim population, zakah potential in Indonesia is around 3.4 percent of total GDP, or equivalent to IDR 127 trillion. This amount will rise sharply in upcoming years, in line with the growth in the economy (Beik \& Arsyianti, 2016). In other words, the multiplier effect of zakah on economic growth is enormous.

Technically, the disbursement of zakah is expected to stabilise beneficiaries' financial condition, allowing them to purchase their basic needs. Previous empirical studies, as mentioned at the beginning of the paper, have demonstrated this positive relationship. Therefore, zakah is further expected to have a positive impact on aggregate consumption. In this regard, Suprayitno, Kader and Harun (2013), using panel data from the Malaysian peninsula, confirmed that the distribution of zakah had a small positive effect on aggregate consumption in the short term. Theoretically, an increase in aggregate consumption will further drive aggregate production. In other words, zakah should have a positive relationship with aggregate production.

This interconnectedness between zakah and other economic sectors makes its role in the economy another example of a complex system. Zakah first has a direct impact on the internal financial situation, which in turns affects the purchasing power of its recipients. As a higher number of individuals are able to buy products, this will affect total aggregate consumption and drive business sectors to increase production. As previously stated, a complex system captures the interactions of all the agents within it (of economic). Earlier empirical literature, however, has left unanswered the question of the extent to which zakah may affect aggregate production, since consumption-based zakah has an indirect effect on economic growth. This issue is hence the central focus of observation in this study.

\subsection{Previous Studies}

Two pioneer studies of ABM, especially in economics, are the work of Schelling (1971, 1978) and Epstein and Axtell (1996). Schelling (1971, 1978) explains the reason why segregation occurs in society. The outcome of his simulation shows that segregation occurs when each individual has a low tolerance of diversity, a fact which could be used to explain economic phenomena, such as why people migrate from suburban areas to cities, or why there are disparities between different regions in a state. Epstein and Axtell (1996) built an artificial model of society called Sugarscape, consisting of a society of agents whose social mutual action included lending and trading activities. The outcomes of the simulation 
generated some important findings, for example, the patterns of agents' migration, variations in population size, and the pattern of wealth distribution.

After Epstein and Axtell (1996) had created the Sugarscape model to analyse wealth distribution in society, economics research on ABM started to be published, such as the work of Rahman (2012), and Rahman, Setayeshi, \& Zafarghandi (2007, 2009b, 2009a). Nevertheless, there has been limited ABM research published in the area of Islamic economics. Consequently, research on zakah based on an ABM simulation is limited. Interestingly, all ABM simulations in the area of Islamic economics and finance have been run using NetLogo, developed by Wilensky and Rand (2015). NetLogo will be explored further in section three.

The initial publications on ABM in Islamic economics can be traced to Al-Suwailem (2008, 2011). Al-Suwailem shows that charity can enhance the consumption of both donors and receivers, observing that there is a general rise in average and median consumption in all scenarios. The simulation results shows that charity is useful in reducing the level of inequality in consumption and raising aggregate consumption. Another study on ABM conducted by Al-Suwailem (2011) shows that wealth is better distributed under an interest-free based system. This study suggests the promotion of interest-free lending in order to create equal wealth distribution in society.

Recently, ABM research in the area of Islamic economics has started to be developed by the IslamicFinancial Engineering(IFE) laboratory at the Mohammadia School of Engineering in Morocco. The laboratory was established in 2015, with one of the main advisory committee members being Al-Suwailem, i.e. the pioneer of ABM development in Islamic economics and finance. IFE produced a total of eight studies during the two year period 2015-2017. Three works by Aaminou and Rajae (2016), Bensaid et al. (2017) and Boularhmane and Souissi (2016) built an ABM to observe dynamic changes in the economy. The other five studies need to be developed as their simulations have yet to be run. These five studies include those of Bourhime and Tkiouat (2016), who explain that microfinance is a complex system; Elhachami and Tkiouat (2016), who modelled consumer goods; Naciri and Tkiouat (2016), who reviewed the use of ABM in economics; and Mohamed and Khadija (2015), who attempted to model the Moroccan economy.

\section{METHODOLOGY}

\subsection{Agent-Based Computational Model}

The study employed the agent-based computational model (ABM). In the area of economics, ABM is defined as a computational study of artificial economies, modelled as evolving systems of autonomous interacting agents. An artificial economy evolves over time, as its constituent agents repeatedly interact with each other and learn from their interactions. The "agent" in ABM refers broadly to bundled data and behaviour methods representing an entity constituting part of a computationally constructed world. Possible agents may include individuals, social groupings, institutions, and biological and physical entities. Moreover, agents can be composed of other agents, thus permitting hierarchical constructions; for example, a firm might be composed of workers and managers (Tesfatsion, 2011). 
The main advantage of ABM is its ability to observe the dynamics of a system and hence answer how and why questions; for example, how equilibrium is achieved, if it is achieved at all, or why a system can be in disequilibrium for a long period. The ABM model also has the ability to study complex interdependent systems. Examples include the ability to model multiple markets, interactions between markets and policies, and a wide variety of heterogeneous actors and institutions (Barr, Tassier, \& Ussher, 2011).

One fundamental departure of ABM modelling from more standard approaches is that events are driven solely by agent interactions once the initial conditions have been specified. Therefore, rather than focusing on the equilibrium states of a system, the idea is to observe if some form of equilibrium develops over time.

A second key departure is the increased facility provided by agent-based tools for agents to engage in flexible social communication. This means that agents can communicate with other agents at event-driven times using messages that they themselves have adaptively scripted.

\subsection{Data: Initialisation}

This research refers to the work of Assenza, Gatti, \& Grazzini (2015) in determining the initial conditions and parameters. The model in this research involves 3000 households, 200 entrepreneurs, and 200 consumption firms, together with a conventional bank. In the NetLogo platform, there are 200 grids, with one grid connected to one entrepreneur and one firm. The initial conditions and parameters for each variable are listed in Table 1.

Table 1.

Initial Conditions and Parameters

\begin{tabular}{lc}
\hline Parameter & Initial Condition \\
\hline Number of periods & 3000 \\
Number of workers & 3000 \\
Number of firms & 200 \\
Marginal productivity of labour & 0.5 \\
Marginal productivity of capital & $1 / 3$ \\
Probability of investing & 0.25 \\
Wages & 1 \\
Firm liquidity & 10 \\
Capital & 10 \\
Production & 5 \\
Bank equity & 3000 \\
Household wealth & 2 \\
Interest rate on credit & $6 \%$ p.a \\
Interest rate on deposits & $2 \%$ p.a \\
Dividend payout ratio & 0.2 \\
Marginal propensity to consume & 0.05 \\
\hline
\end{tabular}




\subsection{Model Development: Conceptual Model}

The model of this research develops the work of Al-Suwailem (2008). There are three types of agent in the model: households $(i=1,2,3, . . \mathrm{H})$, firms $(f=1,2,3, \ldots$, $\mathrm{F})$, and banks $(\mathrm{b}=1,2,3, \ldots \mathrm{B})$. Agents commence decisions at discrete times $(t=1$, $2,3, \ldots \mathrm{T})$ and all agents are heterogeneous, have bounded rationality and follow behaviour rules based on adaptive expectations. The most important differences from Al-Suwailem (2008) include:

1. Introduction of a business sector, i.e. firms

2. Introduction of a goods market

3. Introduction of a labour market

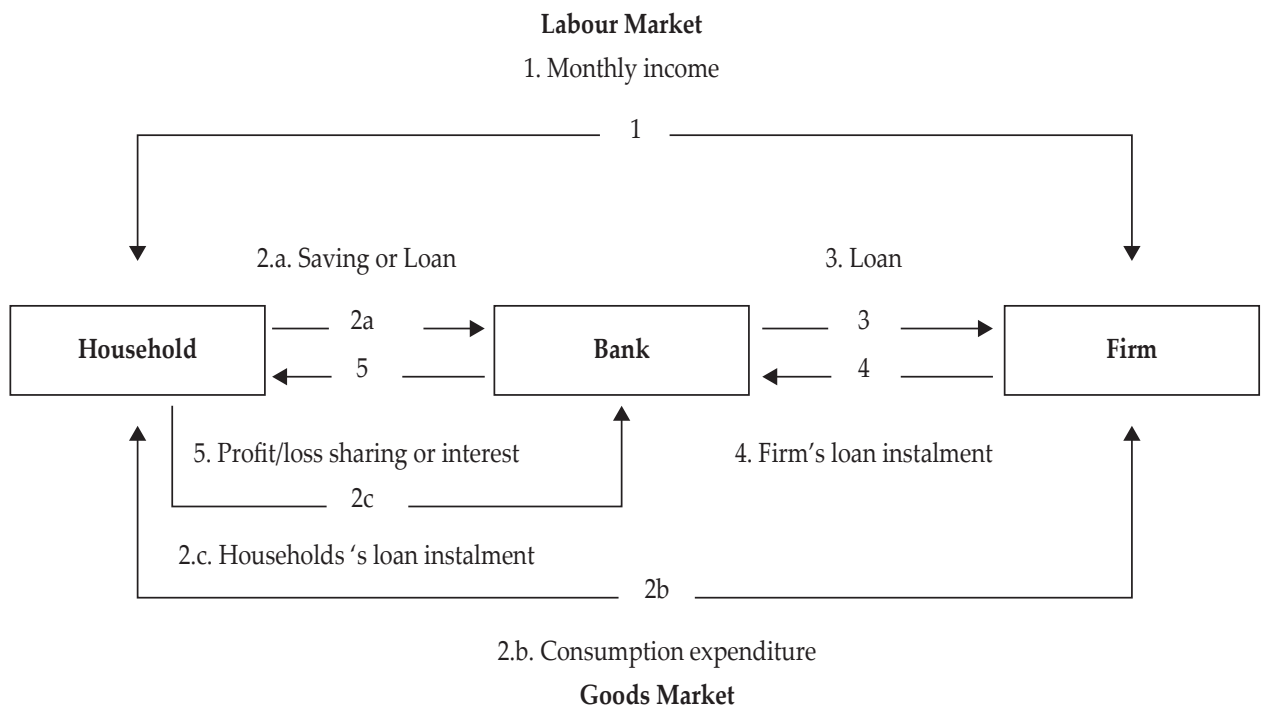

Source: Author's own elaboration

\section{Figure 1 .}

Circular Flow

Figure 1 shows the interconnection between households, firms and banks. Following Gaffeo, Delli, \& Desiderio (2008) and Lengnick (2013), the economy is structured with the absence of a market clearing mechanism. As a consequence, the market allows for the existence of unemployment and excessive household demand. The model also allows for firms to compete with each other or to go bankrupt. It is possible for firms to offer different prices depending on their internal conditions and the demand for the products. Therefore, the 'market' in this research will have features similar to the market in the real world. The introduction of banks is to facilitate agents who have excess money and those who need money.

Based on Figure 1, the sequence or process overview and scheduling in each period of circular flow can be explained as follows: 
1. It is assumed that each household at the beginning of period $t$ has a consumption plan. Employed households earn income paid by the firms. The household sector supplies the labour market. In addition, each firm has capital, investment planning, and technology.

2. Households decide on consumption and savings allocation based on their income, while firms supply a certain quantity of products at different prices and make either a profit or loss depending on their unsold products. Since one period equals 1 month, it is assumed that agents $i$ buy a product for one month . If households decide to put aside a proportion of their income as savings, they will receive interest paid by the banks. Savings are considered to be wealth. However, if household consumption exceeds their income, they will ask for loans and will need to pay monthly instalments.

3. One scenario is the introduction of zakah into the system, which is treated as an exogenous variable. It is given to all agents who are indebted and cannot pay back their loans. All agents who meet the criteria will receive zakah equal to their needs. In other words, in an economy without zakah, agents who cannot meet their financial needs will apply for loans from the bank. However, in an economy with zakah, financial support can be secured through a bank loan or zakah. The amount of zakah equals the minimum consumption of the respective households.

4. Firms set the targeted number of products to be produced and the number of workers who will be employed. This decision is based on past demand. Subsequently, the entrepreneur decides whether the firm needs financing.

5. If a firm decides to apply for loans for investment, the firm owner should pay monthly instalments. Banks therefore play a role as a medium for saving and borrowing. In each period, each household and firm can only ask for financing from one bank, after which the instalment phase starts. Each household and firm evaluates whether they can meet the debt repayment obligations.

6. If depositors decide to keep the monthly interest rate as an additional deposit (saving), the total wealth of depositors will increase. As stated, savings are considered to be a form of wealth. At this point, there will be a change in the distribution of income and wealth amongst the economic agents in the economy.

7. If individual households and firms are unable to pay back their loans, new firms or households will be introduced into the system. In this way, the number of households and firms will be constant throughout the simulation.

By involving three main economic sectors in the simulated model, the outcomes are expected to explain the differences or similarities in wealth distribution before and after zakah enforcement.

\subsection{Simulation Scenarios}

Both firms and households can apply for loans in interest-based lending scenarios. Firms can ask for loans to finance their business, while households can ask for consumption loans. For each loan rate, there will be a different deposit rate. The results of the study should show whether different loan rates and deposit rates will have different or similar impacts on the share of consumption before and after zakah disbursement. 
Table 2.

Scenario of Economy Without and With Zakah

\begin{tabular}{lcccc}
\hline \multicolumn{5}{c}{ Without Zakah } \\
\hline & $\begin{array}{c}\text { Interest rate } \\
\text { on loans (\%) }\end{array}$ & $\begin{array}{c}\text { Interest rate } \\
\text { on deposits (\%) }\end{array}$ & Total scenarios \\
\hline Scenario 1 & 6 & 2.3 & 2 \\
Scenario 2 & 5 & 2.3 & 2 \\
& \multicolumn{5}{c}{ Total } & 4 \\
\hline \multicolumn{5}{c}{ With Zakah } \\
\hline Interest rate on loans & Interest rate & Total cenarios \\
\hline Scenario 1 & $(\%)$ & on deposits (\%) & 2 \\
Scenario 2 & 6 & 2.3 & 2 \\
& 5 & & Total & 4 \\
\hline
\end{tabular}

\subsection{Software: NetLogo}

To construct the agent-based environment, NetLogo@ was employed, a software package developed by Prof. Uri Wilensky at Northwestern University (Wilensky \& Rand, 2015). NetLogo(C is widely used both as a research and teaching tool, as it includes a modelling environment apt for simulation of complex systems and social phenomena (Freeman, 2005). NetLogo is software with a low-threshold ABM language which is fundamentally aimed at minimising the time required to build an ABM, as well as reducing misunderstanding between the conceptual modeller and programmer.

NetLogo also allows thousands of independent agents to act and communicate with each other in a spatial environment. In other words, it can create an ABM which is composed of multiple agents with specific attributes, who interact following adaptive behaviour. Therefore, NetLogo $\subset$ can observe emergences at the macro level from the interaction of each agent at the micro level.

\section{RESULTS AND ANALYSIS}

\subsection{Results}

\subsubsection{Validation}

This section aims to validate whether the model corresponds to four main stylised facts. Validation is a process to ensure whether the simulated model links to and describes certain facts in the real world. In other words, it is not a process to compare the value of empirical and simulated data. Three steps were taken to validate the simulated model:

a. Retrieving empirical data

Four stylised facts were used for validation, namely GDP, consumption, investment and the unemployment rate $^{3}$. All the empirical data were retrieved

\footnotetext{
3 Since empirical data on the Gini index are not complete and are very sparse, validation on the index cannot be conducted.
} 
from the FED of St. Louis website, with a time span of 1947 quarter 1 to 2018 quarter 4. Based on the available data, the unemployment rate runs from 1960 quarter 1 to 2018 quarter 4.

b. Isolating cyclical component

King and Rebelo (1999) observe that most real quantities, e.g. GDP, grows over time, which makes it difficult to pinpoint their fluctuations during a specified period. Therefore, it was necessary to remove the cyclical components of the series using the Hodrick-Prescott (HP) filter.

c. Calculating standard deviation

After all the variables had been detrended using the HP filter, the next step was to calculate the standard deviation. The closer the value of standard deviation between the simulated and empirical data, the more valid the simulated model. The results of the comparison between the simulated and empirical data are shown in Table 3.

Table 3.

Standard Deviation between Empirical and Simulation Data

\begin{tabular}{lcc}
\hline Variable & & Std.Deviation \\
\hline \multirow{2}{*}{ GDP } & Empirical & 2.917 \\
& Simulation & 4.989 \\
Consumption & Empirical & 2.549 \\
& Simulation & 3.47 \\
Investment & Empirical & 17.153 \\
& Simulation & 16.436 \\
Unemployment & Empirical & 1.652 \\
& Simulation & 0.568 \\
\hline
\end{tabular}

Source: Authors' own calculations

Based on Table 3, the standard deviation of the data generated from the simulation is relatively similar to the empirical data. In other words, the research model is able to simulate important phenomena in the real world.

\subsubsection{Simulation Results}

This section explores the findings based on data from the simulation. Each model was run 15 times, with time spans covering 2000 periods in order to ensure the robustness of the results. To remove transient behaviour of the agents, data from the first 300 periods were discarded, hence the total data for analysis comprised 1700 periods.

Similar to previous studies on the impact of zakah on aggregate consumption, the outcome of the simulation confirms that the existence of zakah in the economy may drive aggregate consumption up (Figure 2). The red line represents the scenario of an economy without zakah, while the blue line represents that of an economy with zakah. The simulation results show that in all scenarios (boxes A, B, C and D within Figure 2), aggregate consumption in an economy with zakah is higher than that in an economy without zakah. 
A. Interest on Credit $=6 \%$

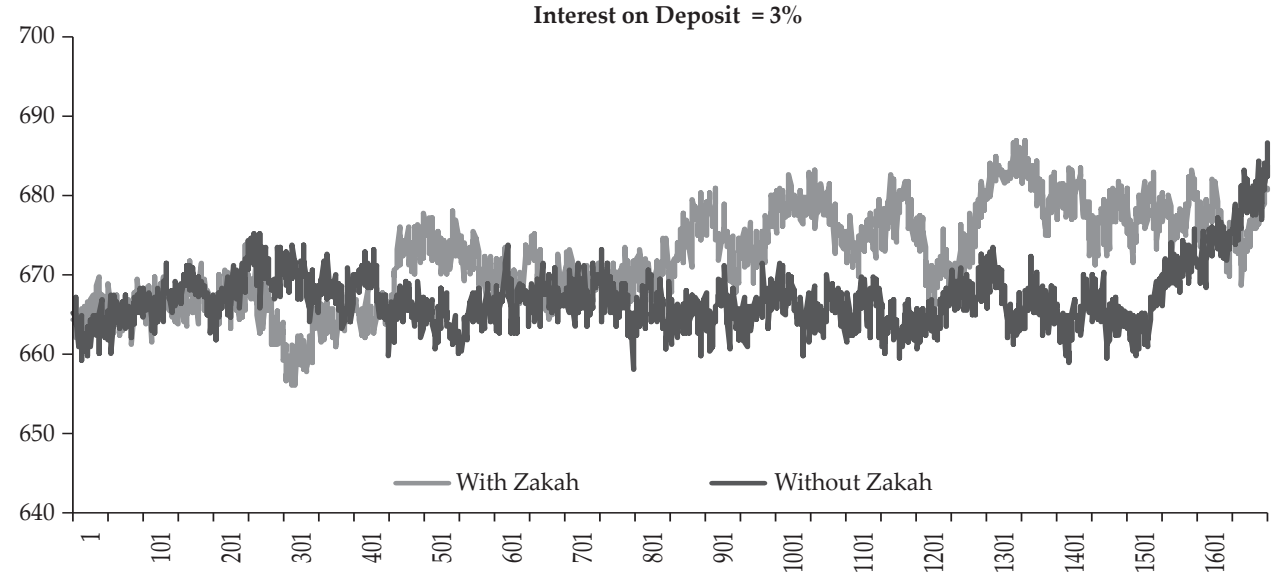

B. Interest on Credit $=6 \%$

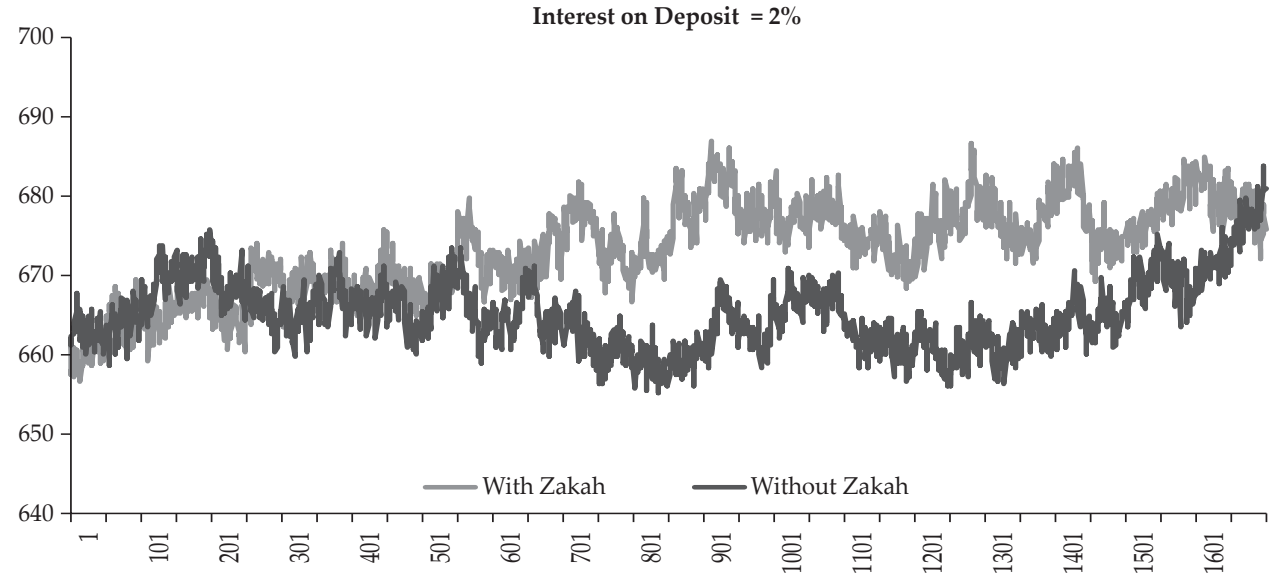

C. Interest on Credit $=5 \%$

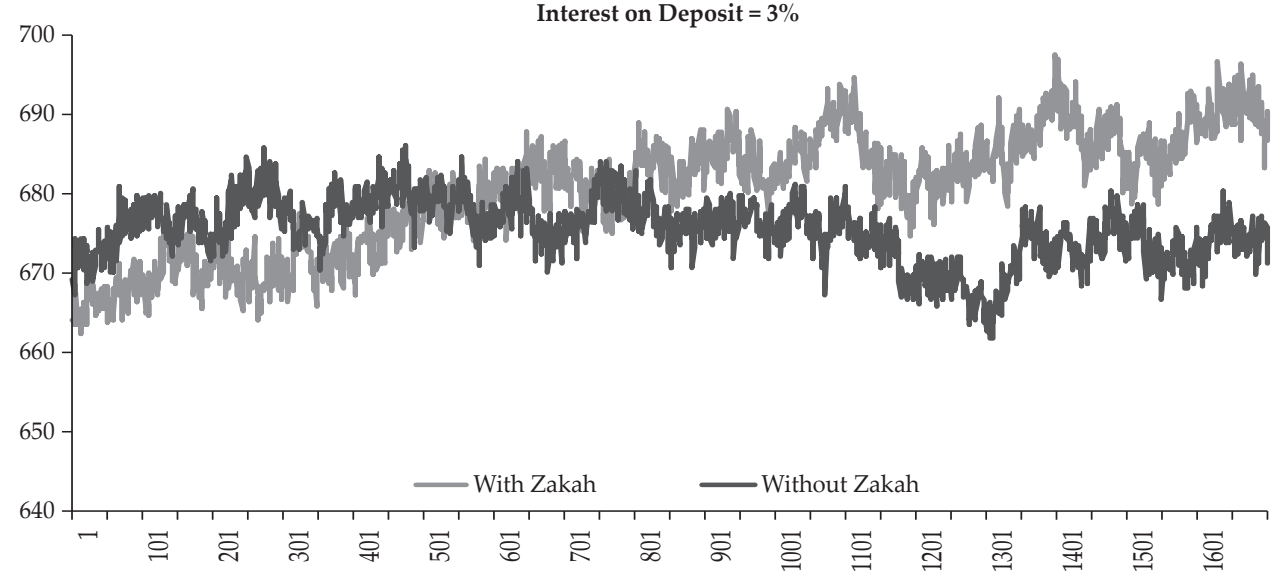

Source: Authors' own elaboration

Figure 2 .

Comparison of Level of Consumption in Economies With and Without Zakah 


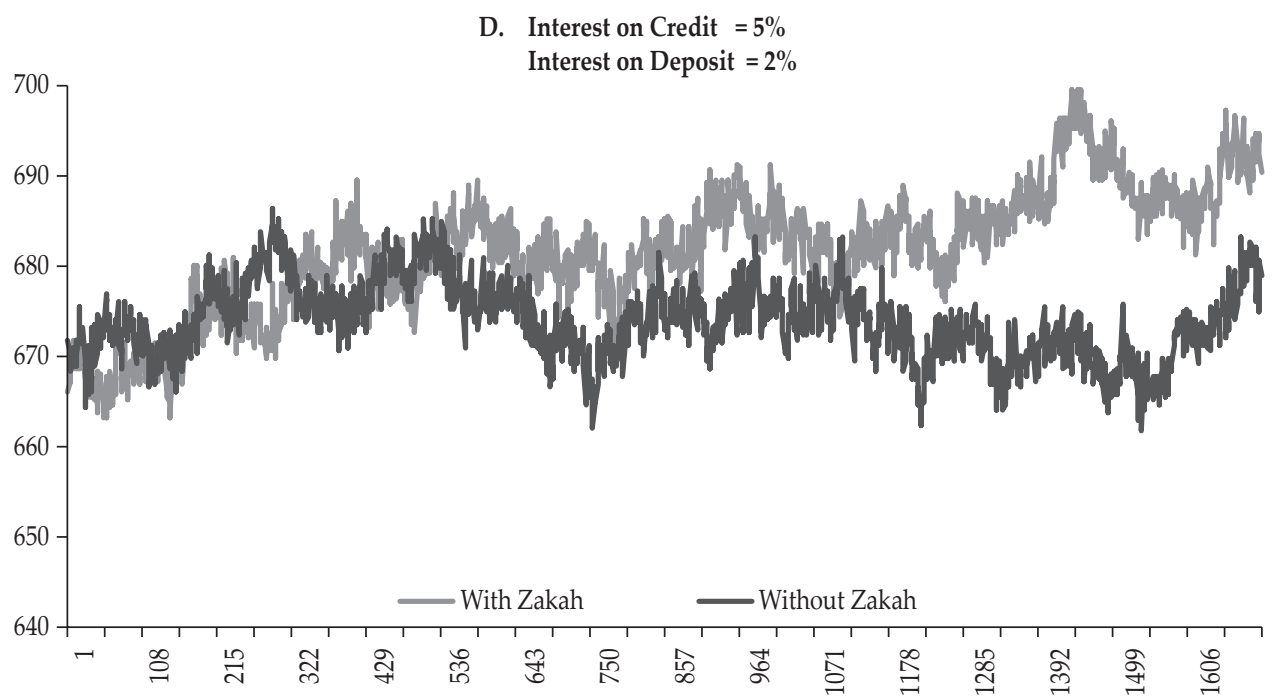

Source: Authors' own elaboration

Figure 2 .

Comparison of Level of Consumption in Economies With and Without Zakah

(Continued)

Table 4 also confirms that average aggregate consumption in the economy with zakah scenario is also higher than in the without zakah scenario. The results presented in Figure 3 and Table 3 support the notion that the interest rate on credit has a negative impact on the level of aggregate consumption in both scenarios. Specifically, the economy experiences a lower level of aggregate consumption with the interest rate on credit at 6 percent; however, aggregate consumption tends to be higher when the rate is reduced to 5 percent.

Table 4.

Average Consumption in Economies With and Without Zakah

\begin{tabular}{lccc}
\hline Interest on Credit & Interest on Deposits & Without Zakah & With Zakah \\
\hline \multirow{2}{*}{$6 \%$} & $3 \%$ & 667.033 & 672.333 \\
& $2 \%$ & 665.165 & 673.338 \\
\multirow{2}{*}{$5 \%$} & $3 \%$ & 675.474 & 680.409 \\
& $2 \%$ & 673.902 & 681.641 \\
\hline
\end{tabular}

Source: Authors' calculation

Zakah has a direct impact on the purchasing power of individual households and will minimise the number of households falling into bankruptcy (Figure 3) ${ }^{4}$. This lower number means there will be more households that can buy products

4 Other scenarios also show a similar phenomenon, that the number of bankrupt households is lower in an economy with zakah. 
sold on the market. Therefore, aggregate consumption in an economy with zakah is higher than that in an economy without zakah.

Bankrupt Households

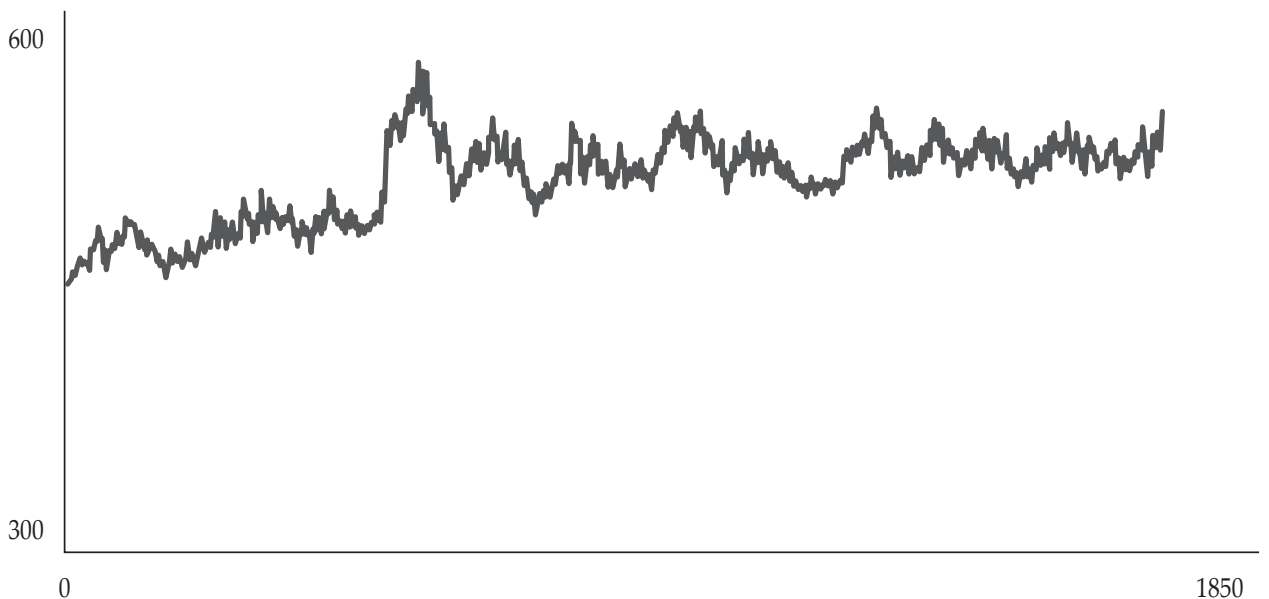

Bankrupt Households

600

300

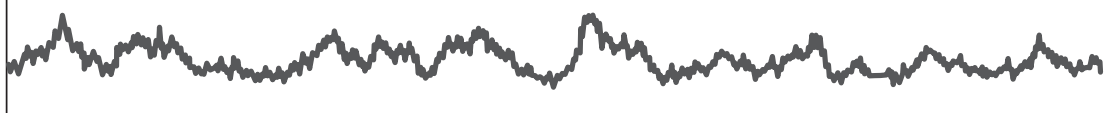

0

Note: Simulation results based on interest on credit at $6 \%$ and interest on deposits at $2 \%$

Figure 3.

Comparison of Number of Bankrupt Households in Economies With and Without Zakah

Table 5.

Correlation between GDP and Consumption

\begin{tabular}{lc}
\hline Variable & Correlation \\
\hline Consumption - GDP & 0.611 \\
\hline Note: In a scenario with interest on credit at $6 \%$ and interest on deposits at $2 \%$
\end{tabular}


Theoretically, an increase in aggregate consumption will have a positive impact on aggregate production; Table 5 confirms that there is a strong positive relationship between them (represented by GDP). The correlation result further implies that aggregate production should also be higher in an economy with zakah than without it.

Figure 4 confirms that in all scenarios (boxes A, B, C and D inside Figure 3 ), the level of GDP in an economy with zakah (red line) is higher than that in an economy without zakah (blue line). In addition, the movement of GDP in an economy with zakah continues to increase at a relatively stable rate.
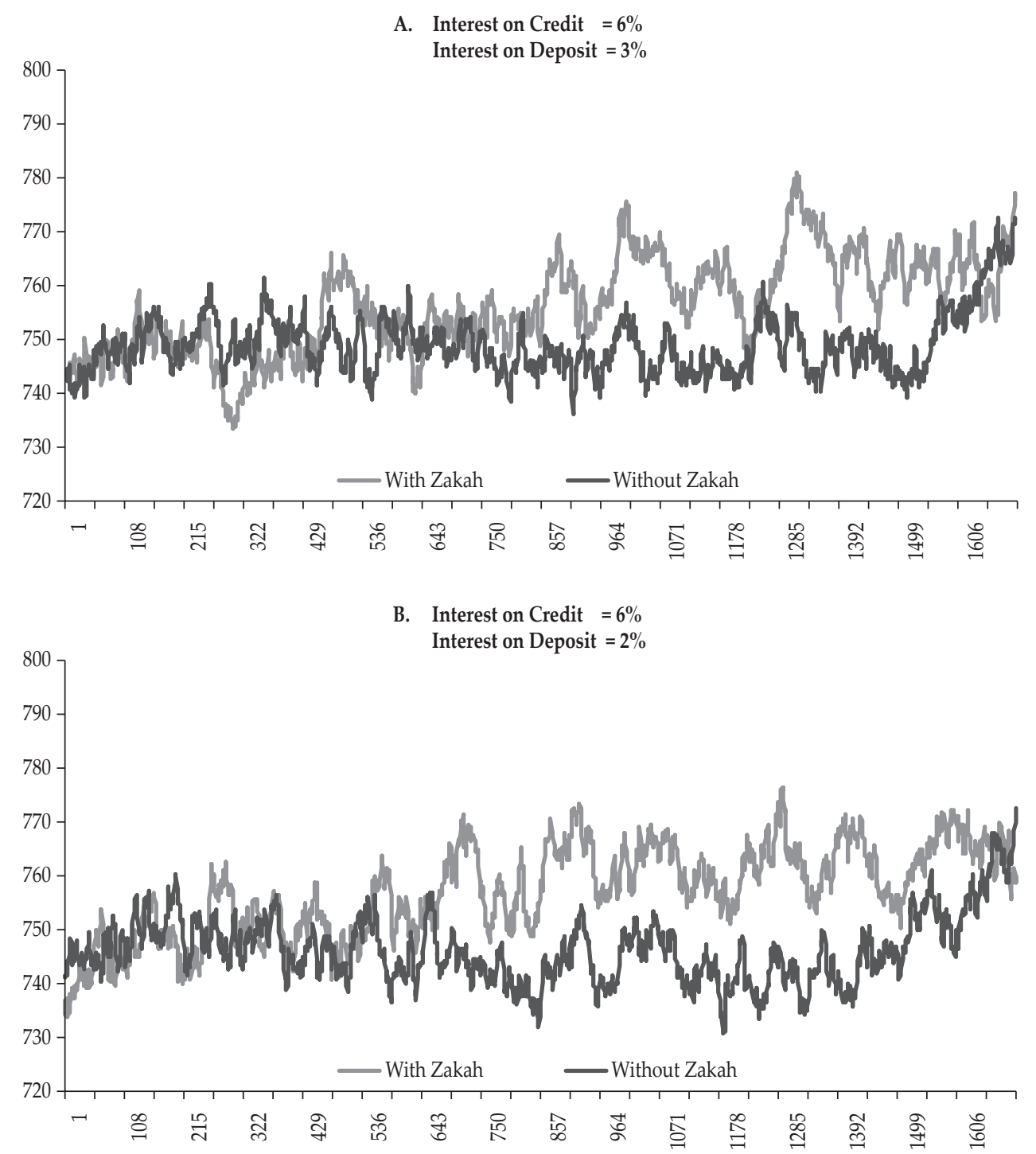

Source: Authors' own elaboration

Figure 4.

Comparison of Level of GDP in Economies With and Without Zakah 
C. Interest on Credit $=5 \%$

Interest on Deposit $=3 \%$

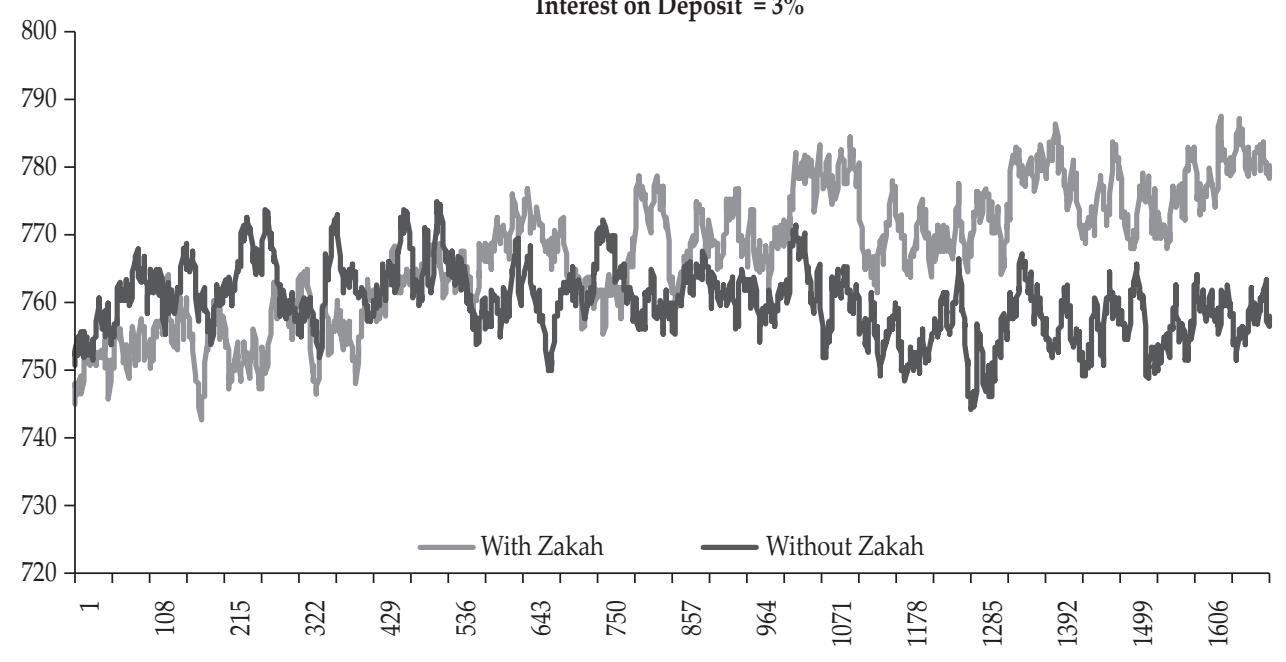

D. Interest on Credit $=5 \%$

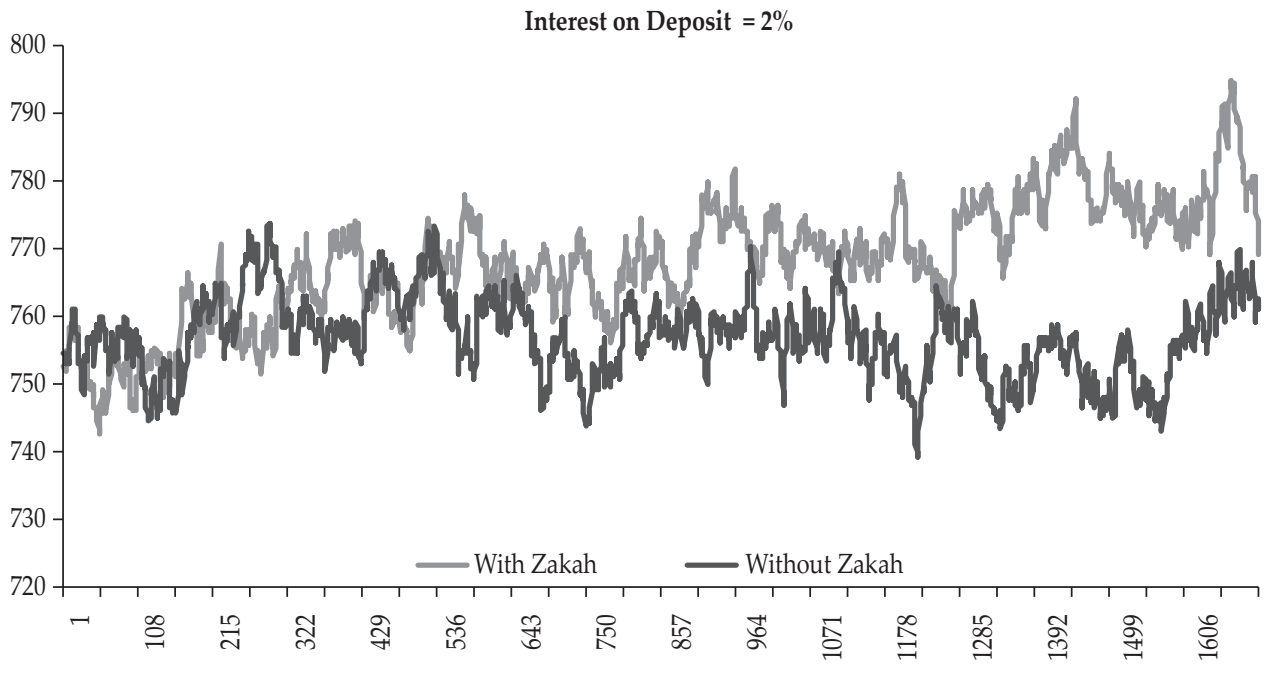

Source: Authors' own elaboration

Figure 4 .

Comparison of Level of GDP in Economies With and Without Zakah (Continued)

Table 6 confirms that the average level of GDP in an economy with zakah is higher than in one without zakah. The results shown in Figure 4 and Table 5 also indicate that the interest rate on credit harms the level of GDP, both in economies with and without zakah. In this regard, a higher interest rate on credit will lead to a lower level of GDP, and vice versa. Therefore, the level of GDP at a credit interest rate of 6 percent is lower than that at a rate of 5 percent. 
Table 6.

Average GDP in Economies With and Without Zakah

\begin{tabular}{lccc}
\hline Interest on Credit & Interest on Deposits & Without Zakah & With Zakah \\
\hline \multirow{2}{*}{$6 \%$} & $3 \%$ & 749.009 & 756.217 \\
& $2 \%$ & 746.213 & 757.053 \\
\multirow{2}{*}{$5 \%$} & $3 \%$ & 759.981 & 767.205 \\
& $2 \%$ & 756.948 & 768.086 \\
\hline
\end{tabular}

Source: Authors'own calculation

\subsection{Analysis}

Unlike Timsina and Pradhan (2017), Bongini et al. (2017), Okaro (2016), Timsina (2014), Jotwani (2014), Atiq and Haque (2014), Ostry et al. (2014), Raz (2013), Ugoani (2013), Acha (2011), Kenourgios and Samitas (2007) and Santha et al. (2003), among many others, who showed that bank lending can stimulate aggregate production and hence promote economic growth, this research has shown that zakah is a powerful instrument in driving the level of aggregate production (GDP). Furthermore, previous ABM works, such as those of Rahman $(2009,2012)$ and Al-Suwailem $(2008,2011)$, have shown that charity can have a positive impact on consumption due to its direct impact on the wealth of beneficiaries. In this regard, zakah also has a direct impact on the total consumption of beneficiaries, as shown by the lower number of bankrupt households. This lower number means that there will be more households who can fulfil their desired consumption. As a result, GDP in an economy with zakah is higher than that in an economy without zakah. At this point, this simulation result has filled the gap of previous empirical studies ${ }^{5}$ which have assumed that zakah has a direct impact on economic growth, showing that the two variables essentially have an indirect relationship.

The simulation results also show that when zakah does not exist, the economy experiences lower growth. This implies that interest-based lending does not have a positive impact on economic growth. Some previous ABM works on inequality further found that interest-based lending will create higher inequality (represented by the Gini index) compared to markup-based financing (Al-Suwailem, 2008, 2011; Boularhmane \& Souissi, 2016) and even interest-free lending (Rahman, 2012). Therefore, this study argues that bank lending may indeed promote economic growth. However, the growth experiences more fluctuations and is not as high as that when zakah is introduced into the system. Therefore, this research further questions previous studies (which have shown that bank lending may promote economic growth) concerning the extent to which bank lending promotes equitable economic development compared to zakah.

\section{CONCLUSION AND RECOMMENDATIONS}

\subsection{Conclusion}

Many thoughts on and approaches to Islamic economics teaching remain undeveloped, although the significant developments in technology and

5 Khasandy and Badrudin (2019), Sarea (2012), Azam et al. (2014) and Ridwan et al. (2019). 
informatics should benefit Islamic economics research. The application of an agent-based computational model (ABM) in this study intends to facilitate the use of computational study as an alternative method of developing such research. In this case, the use of ABM has aimed to explore and answer a fundamental research problem in zakah which has not been covered in previous studies, namely the extent to which the distribution of zakah for consumption purposes affects aggregate production.

Conventional methodology such as surveys or types of regression are not capable of answering the research question as zakah is a complex system. Islamic economics needs to move forward to benefit from the advances in technology in order to deal with many of the research problems that have not been previously discussed. The use of ABM is one approach that can be employed.

\subsection{Recommendations}

Indonesia, as the most populated Muslim country in the world, needs to have comprehensive regulations related to zakah. This research has formulated policy recommendations by analysing the results of the simulation, reviewing previous studies and conducting an interview with a zakah expert ${ }^{6}$. Three fundamental dimensions to improve regulations on zakah in Indonesia have been revealed.

a. Policies related to the collection of zakah

It is suggested that zakah be made obligatory for those who are categorised as muzaki. If zakah were to become an obligation for all muzakis, it would mean that zakah would be formally introduced into the system. Indonesia, as a majority Muslim country, has high potential to impose zakah on its citizens. In the long term, it is expected that zakah would support the Indonesian government in reaching its development goals.

b. Policies related to the distribution of zakah

Zakah is commonly distributed for consumption purposes. The simulation results show that the disbursement of consumption-based zakah may have a positive impact on economic growth in the long term. At the same time, if zakah is distributed to the supply side, especially to micro, small and medium enterprises (MSMEs), it may have a yet greater impact, as the production of MSMEs will be higher and they will not need financing, which requires the payment of monthly instalments. The final goal of disbursement, therefore, is to transform zakah recipients (mustahik) into zakah payers in the future.

\footnotetext{
6 Authors conducted an interview with Dr. Qurroh Ayuniyyah, M.Ec. a project manager at the Center for Islamic Economics International Islamic University Malaysia (CIE IIUM) on 17 July 2019.
} 
c. Recommendations for practitioners

Zakah institutions should have continuous monitoring programmes to supervise and empower the mustahik. The final policy is related to the process of selecting potential mustahik in order to ensure that zakah is given only to eligible persons. Ayuniyyah et al. (2017) confirm that there are mustahik who already live above the poverty line.

\section{FURTHER RESEARCH}

This study is the authors' first research project and therefore only covers consumption-based zakah. It does not examine the role of zakahon aggregate production. Therefore, the research could be developed by including productionbased zakah in the model. It is expected that the outcome would enable examination of the differences or similarities in aggregate production before and after the disbursement of production-based zakah.

In addition, it is suggested that future research treats zakah in terms of endogenous variables and determines the rate of zakah payment. Therefore, the simulation results could examine the full impact of both consumption-based and production-based zakah in the economy.

\section{REFERENCES}

Aaminou, M. W., \& Rajae, A. (2016). Leveraging Ethics to Expand Islamic Banks' Customer Base: A Fuzzy Agent-Based Modeling Approach. Asian Journal of Applied Sciences, 04(03), 558-574.

Acha, I.A. (2011). Financial Intermediation by Banks and Economic Growth in Nigeria, 1990 - 2008 (2011). Journal of Economics and Sustainable Development, 2(4), Available at SSRN: https://ssrn.com/abstract=2761567

Ahmed, H. (2004). Role of Zakah and Awqaf in Poverty Alleviation. Jeddah: Islamic Development Bank, Islamic Research and Training Institute.

Akbar, N., \& Kayadibi, S. (2013). Opportunity and Challenges to Integrate Zakat Into Indonesian Fiscal System in The Light of Siyasah Shar'iyyah. Global Review of Islamic Economics and Business, 1(1), 57-69. https://doi.org/10.1017/ CBO9781107415324.004

Al-suwailem, S. (2007). Islamic Economics in A Complex World: Explorations in Agentbased Simulation. Complexity. Retrieved from http://www.irti.org/English/ Pages/Publications.aspx

Al-suwailem, S. (2011). Behavioral Complexity. Journal of Economic Surveys, 25(3), 481-506.

Al-Suwailem, S. (2008). Islamic Economics In A Complex World: Explorations in Agentbased Simulation. Complexity. Jeddah: King Fahad National Library Catalogingin-Publication Data Islamic Development Bank.

Arthur, W. B. (2013). Complexity Economics: A Different Framework for Economic Thought (012 No. 04).

Assenza, T., Gatti, D. D., \& Grazzini, J. (2015). Emergent Dynamics of a Macroeconomic Agent Based Model with Capital and Credit. Journal of Economic Dynamics and Control, 50, 5-28. https://doi.org/10.1016/j.jedc.2014.07.001 
Atiq, Z., \& Haque, M. E. (2014). Financial Development and Economic Growth: The Role of Financial Liberalization. Available at SSRN: https://ssrn.com/ abstract $=2407358$ or http://dx.doi.org/10.2139/ssrn.2407358

Ayuniyyah, Q., Pramanik, A. H., Saad, N., \& Ariffin, I. (2017). The Comparison Between Consumption and Production-based Zakat Distribution Programs for Poverty Alleviation and Income Inequality Reduction, 2(2), 11-28.

Azam, M., Iqbal, N.,\& Tayyab, M. (2014). Zakat and Economic Development: Micro and Macro Level Evidence from Pakistan. Bulletin of Business and Economics, 3(2), 85-95.

Barr, J., Ussher, L., \& Tassier, T. (2011). Introduction to the Symposium on Agentbased Computational Economics. Eastern Economic Journal, 37, 1-5. 10.1057/ eej.2010.65.

Bello, D. A. (2010). Poverty Alleviation through Zakah and Waqf Institutions: A Case for the Muslim Ummah in Ghana (10 No. 23191). Zaria-Nigeria.

Beik, I. S., \& Arsyianti, L. D. (2016). Ekonomi Pembangunan Syariah. Jakarta: PT. Raja Grafindo Persada

Bensaid, K., Mouad, A., Haloui, E., Naciri, N., \& Aboulaich, R. (2017). Agent Based Modeling of Islamic Microfinance with Cooperatives and Takaful System. International Journal of Applied Business and Economic Research, 15(5), 737-756.

Bongini, P., Iwanicz-Drozdowska, M., Smaga, P., \& Witkowski, B. (2017). Financial Development and Economic Growth: The Role of Foreign-Owned Banks in CESEE Countries (2017). Sustainability (MDPI Open Access), 2017, 9(3), 335; should there be a journal name? Page range?doi:10.3390/su9030335. Available at SSRN: https://ssrn.com/abstract=2966678

Boularhmane, I., \& Souissi, M. A. (2016). Corporate Islamic Financing In A Complex Economy. International Journal of Applied Engineering Research, 11(14), 8171-8176.

Bourhime, S., \& Tkiouat, M. (2016). Microfinance Overview : From Simple Loans to Complex Systems. Asian Journal of Applied Sciences, 04(01), 87-94.

Chapra, M. U. (1979). The Islamic Welfare State and its Role in the Economy. Studies in Islamic Economics. Leicester, UK: The Islamic Foundation. https://doi. org/10.1017/CBO9781107415324.004

Elhachami, K., \& Tkiouat, M. (2016). Towards an Agent-Based Modeling of the Consumer Goods Market. Asian Journal of Applied Sciences, 04(02), 276-285.

Epstein, J. M., \& Axtell, R. (1996). Growing Artificial Societies. Massachusetts Avenue : MIT Press.

Freeman, T. R. (2005). From the Ground up: an Agent-based Model of Regional Structural Change. University of Saskatchewan. Retrieved from: https://www.dropbox. com/s/4r1zw7pur42hvu1/2005_Freeman_Thesis.pdf?dl=0

Gaffeo, E., Delli, D., \& Desiderio, S. (2008). Adaptive Microfoundations for Emergent Macroeconomics, (3), 441-463. https://doi.org/10.1057/eej.2008.27

Hassanain, K., \& Saaid, A.E. (2016). Zakah for Poverty Alleviation: Evidence from Sudan. International Research Journal of Finance and Economics, 1(154), 83-102. Retrieved from http://www. internationalresearchjournaloffinanceandeconomics.com

Hoque, N., Khan, M. A., \& Mohammad, K. D. (2015). Poverty Alleviation by Zakah in a Transitional Economy: a Small Business Entrepreneurial Framework. 
Journal of Global Entrepreneurship Research, 5(7), 1-20. https://doi.org/10.1186/ s40497-015-0025-8

Jaelani, A. (2016). Zakah Management for Poverty Alleviation in Indonesia and Brunei Darussalam. Turkish Economic Review, 3(3), 495-512. https://doi. org/10.1453/ter.v3i3.843

Jotwani, D.,(2014), The Role of Bank Credit as a Determinant of Economic Growth in India. Adarsh Journal of Management Research, 7(1). Available at: SSRN: https:// ssrn.com/abstract=3195116

Kahf, M. (1999). The Principle of Socio-economic Justice in the Contemporary Fiqh of Zakah. IQTISAD Journal of Islamic Economics, 1-48. Retrieved from http:// monzer.kahf.com/papers/english/socioeconomic_justice.pdf

Kasri, R. A., \& Kassim, S. H. (2009). Empirical Determinants of Saving in the Islamic Banks: Evidence from Indonesia. Journal of King Abdulaziz University, Islamic Economics, 22(2), 181-201. https://doi.org/10.4197/islec.22-2.7

Kenourgios, D., and Samitas, A. (2007). Financial Development and Economic Growth in a Transition Economy : Evidence for Poland, 3(1).

Khasandy, E.A. and Badrudin, R. (2019). The Influence of Zakat on Economic Growth and Welfare Society in Indonesia. Integrated Journal of Business and Economics

King, R. G., \& Rebelo, S. T. (1999). Resuscitating Real Business Cycles. Handbook of Macroeconomics, 1 .

Lengnick, M. (2013). Agent-based Macroeconomics: A Baseline Model. Journal of Economic Behavior and Organization, 86, 102-120. https://doi.org/10.1016/j. jebo.2012.12.021

Mohamed, T., \& Khadija, E. H. (2015). The Agent-Based Modeling of the Macroeconomic Behavior of Sharia-Compliant Companies. In International Congress on Islamic Economics and Finance (pp. 1-19). Sakarya.

Naciri, N., \& Tkiouat, M. (2016). Economic Agent Based Models: Review. International Journal of Applied Engineering Research, 11(8), 5492-5502.

Nurlita, E., \& Ekawaty, M. (2018). The Direct and Indirect Effect of Zakat on the Household Consumption of Mustahik (A Study of Zakat Recipients from BAZNAS Probolinggo Municipality). International Journal of Zakat, 3(2), 41-56. Retrieved from https://ijazbaznas.com/index.php/journal/article/view/77

Oh, Y. J. (2015). Agent-Based Network Modeling for the 2008 Financial Crisis and the Sluggish Recovery. The University of Texas at Dallas. https://doi.org/10.1017/ CBO9781107415324.004

Ostry, J. D., Berg, A., \& Tsangarides, C. G. (2014). Redistribution, Inequality, and Growth (IMF Staff Discussion Note No. SDN/14/02). Washington, DC: International Monetary Fund. Retrieved from imf.org/external/pubs/ft/ $\operatorname{sdn} / 2014 / \operatorname{sdn} 1402 . p d f$

Okaro, C.S.O. (2016). Deposit Money Banks' Credit and Nigerian Economic Growth and Development (1981-2015) (October 2016). NG-Journal of Social Development, 5(5). page numbers missingAvailable at SSRN: https://ssrn.com/ abstract $=2919807$

Rahman, A. (2012). Wealth Adjustment Using a No-interest Credit Network in an Artificial Society. AI and Society, 27(4), 535-541. https://doi.org/10.1007/s00146011-0365-z 
Rahman, A., Setayeshi, S., \& Zafarghandi, M. S. (2007). An Analysis to Wealth Distribution based on Sugarscape Model in an Artificial Society. International Journal of Engineering, 20(3), 133-137.

Rahman, A., Setayeshi, S., \& Zafarghandi, M. S. (2009a). Wealth Adjustment in an Artificial Society, Based on a Sugarscape Model Using One Fifth of the Wealth Variable. Iranian Journal of Electrical and Computer Engineering, 8(1), 35-40.

Rahman, A., Setayeshi, S., \& Zafarghandi, M. S. (2009b). Wealth Adjustment Using a Synergy between Communication, Cooperation, and One-Fifth of Wealth Variables in an Artificial Society. AI and Society, 24(2), 151-164. https://doi. org/10.1007/s00146-008-0186-x

Raz, A. (2013). The Nexus between Bank Credit Development and Economic Growth in Indonesia. DLSU Business and Economics Review, 23(1), 93-104. Available at SSRN: https://ssrn.com/abstract $=3084067$

Ridwan, M., Pimada, L., and Asnawi, N. (2019). Zakat Distribution and Macroeconomic Performance: Empirical Evidence of Indonesia. Int. J Sup. Chain. Mgt, 8(3),

Sarea, A. (2012). Zakat as a Benchmark to Evaluate Economic Growth: An Alternative Approach. International Journal of Business and Social Science, 3(18), 2010-2013.

Schelling, T. C. (1971). Dynamic Models of Segregation. Journal of Mathematical Sociology, 1, 143-186. https://doi.org/10.1080/0022250X.1971.9989794

Schelling, T. C. (1978). Micromotives and Macrobehaviors (1st ed.). Toronto: George J. McLeod Limited. https://doi.org/10.2307/2989930

Suprayitno, Eko \& Kader, Radiah \& Harun, Azhar. (2013). The Impact of Zakat on Aggregate Consumption in Malaysia. Journal of Islamic Economics, Banking and Finance, 9(1), 39 - 2. 10.12816/0001592. Ziauddin, A. (1990). Islam, Poverty and Income Distribution. Leicester, U.L.: The Islamic Foundation.

Tesfatsion, L. (2011). Agent-Based Computational Economics: Modelling Economies as Complex Adaptive Systems. Eastern Economic Journal, 37, 40-43. https://doi.org/10.1016/s0020-0255(02)00280-3

Timsina, N., \& Pradhan, R. (2017). Effects of Bank Lending on Economic Growth in Nepal. Journal of Advanced Academic Research, 3(3), 53-75. https://doi. org/10.3126/jaar.v3i3.16810

Timsina, N. (2014). Impact of Bank Credit on Economic Growth in Nepal, NRB Working Paper 22/2014, Nepal Rastra Bank, Research Department.

Ugoani, J. (2013). Power of Bank Credit on Economic Growth: A Nigerian Perspective. International Journal of Financial Economics 1(3), 93-102. Available at SSRN: https://ssrn.com/abstract=2357439

Vaithilingam, S., Guru, B., \& Shanmugam, B. (2003). Bank Lending and Economic Growth in Malaysia. Journal of Asia-Pacific Business, 5, 51-69. 10.1300/ J098v05n01_05.

Wilensky, U., \& Rand, W. (2015). An Introduction to Agent-Based Modeling: Modeling Natural, Social and Engineered Complex System with NetLogo. The MIT Press Massachusetts Institute of Technology. 
This page is intentionally left blank 